\title{
Mast Cell May Be the Master Key to Solve the Mystery of Pathogenesis of Irritable Bowel Syndrome
}

\author{
Hyuk Yoon \\ Department of Internal Medicine, Seoul National University Bundang Hospital, Seongnam, Korea
}

See "Tryptase and Protease-Activated Receptor 2 Expression Levels in Irritable Bowel Syndrome" by Wen-Jing Liang, et al. on page 382-390, Vol. 10. No. 3, 2016

The pathologic role of mast cell was classically studied in allergic diseases such as asthma and anaphylaxis. ${ }^{1}$ However, recently, the role of this multifunctional master cell has been actively investigated in the field of functional gastrointestinal disorder. Activation of mast cell has been suggested to increase intestinal permeability and promote visceral hypersensitivity in irritable bowel syndrome (IBS). ${ }^{2}$ As one of the possible mechanisms, release of tryptase from mast cell, activation of protease-activated receptor 2 (PAR-2), and subsequent release of neuropeptides from afferent neurons in the intestine have been proposed through several studies. ${ }^{3-5}$

In this issue of Gut and Liver, Liang et al. ${ }^{6}$ investigated the expression of tryptase, PAR-2 and several neuropeptides in the colonic mucosal of healthy control and patients with IBS. The authors found that mRNA expression of tryptase and PAR-2 was significantly elevated in the patients with IBS compared to the control. Tryptase protein expression was also elevated in the patients with IBS. However, PAR-2 protein expression did not differ between the IBS patients and the control. The protein level of calcitonin gene-related peptide, vasoactive intestinal peptide, and substance $P$ was significantly higher in the patients with diarrhea-type IBS (IBS-D) than in the control.

This study added precious evidence which supports the role of mast cell in the pathogenesis of IBS. In addition, the elevation of all neuropeptides in IBS-D only well corresponds with the results of some studies which showed mast cell hyperplasia is more common in IBS-D. ${ }^{7,8}$ However, this study has some limitations. The interaction between mast cell and intestinal never is bidirectional. ${ }^{2}$ Neuropeptides can trigger activation of mast cell and conversely, activated mast cell can stimulate release of neuropeptides from nerve terminal. Therefore, elevation of both tryptase and neuropeptides in this study does not tell us which one is first. In addition, elevation of PAR-2 mRNA in the IBS patients did not led to the elevation of PAR-protein in this study. Another pathway which connects tryptase and the pathologic effects in IBS might be possible.

Recently, the role of gut microbiota has been highlighted in the pathogenesis of IBS. ${ }^{9}$ Although there is still no convincing evidence, I think the change of gut microbiota might trigger activation of mast cell and subsequent visceral hypersensitivity. In-depth studies are required regarding the relationship between mast cell and the pathogenesis of IBS, considering the role of this tiny hero.

\section{CONFLICTS OF INTEREST}

No potential conflict of interest relevant to this article was reported.

\section{REFERENCES}

1. Krystel-Whittemore M, Dileepan KN, Wood JG. Mast cell: a multifunctional master cell. Front Immunol 2016;6:620.

2. Wouters MM, Vicario M, Santos J. The role of mast cells in functional GI disorders. Gut 2016;65:155-168.

3. Jacob C, Yang PC, Darmoul D, et al. Mast cell tryptase controls paracellular permeability of the intestine: role of protease-activated receptor 2 and beta-arrestins. J Biol Chem 2005;280:3193631948.

4. Cenac N, Andrews CN, Holzhausen M, et al. Role for protease activity in visceral pain in irritable bowel syndrome. J Clin Invest 2007;117:636-647.

\footnotetext{
Correspondence to: Hyuk Yoon

Department of Internal Medicine, Seoul National University Bundang Hospital, 82 Gumi-ro 173beon-gil, Bundang-gu, Seongnam 13620, Korea

Tel: +82-31-787-7042, Fax: +82-31-787-4051, E-mail: yoonh@snubh.org pISSN 1976-2283 eISSN 2005-1212 http://dx.doi.org/10.5009/gnl16092

(c) This is an Open Access article distributed under the terms of the Creative Commons Attribution Non-Commercial License (http://creativecommons.org/licenses/by-nc/4.0) which permits unrestricted non-commercial use, distribution, and reproduction in any medium, provided the original work is properly cited.
} 
326 Gut and Liver, Vol. 10, No. 3, May 2016

5. Steinhoff M, Vergnolle N, Young SH, et al. Agonists of proteinaseactivated receptor 2 induce inflammation by a neurogenic mechanism. Nat Med 2000;6:151-158.

6. Liang WJ, Zhang G, Luo HS, Liang LX, Huang D, Zhang FC. Tryptase and protease-activated receptor 2 expression levels in irritable bowel syndrome. Gut Liver 2016;10:382-390.

7. Lee KJ, Kim YB, Kim JH, Kwon HC, Kim DK, Cho SW. The alteration of enterochromaffin cell, mast cell, and lamina propria T lymphocyte numbers in irritable bowel syndrome and its relationship with psychological factors. J Gastroenterol Hepatol 2008;23:16891694.

8. Goral V, Kucukoner M, Buyukbayram H. Mast cells count and serum cytokine levels in patients with irritable bowel syndrome. Hepatogastroenterology 2010;57:751-754.

9. Bennet SM, Ohman L, Simren M. Gut microbiota as potential orchestrators of irritable bowel syndrome. Gut Liver 2015;9:318331. 